\title{
Multianalytical Approach to explain the darkening process of hematite pigment in paintings from ancient Pompeii after accelerated weathering experiments
}

\author{
Maite Maguregui, ${ }^{* a}$ Kepa Castro, ${ }^{\mathrm{b}}$ Héctor Morillas, ${ }^{\mathrm{b}}$ Josu Trebolazabala, ${ }^{\mathrm{b}}$ Ulla Knuutinen, ${ }^{\mathrm{c}}$ Rita \\ ${ }_{5}$ Wiesinger, $^{\mathrm{d}}$ Manfred Schreiner $^{\mathrm{d}}$ and Juan Manuel Madariaga $^{b}$
}

\author{
Received (in $X X X, X X X)$ Xth $X X X X X X X X X 20 X X$, Accepted Xth $X X X X X X X X X 20 X X$ \\ DOI: $10.1039 / b 000000 x$
}

In this paper, recently excavated fresco painting fragments from the House of Marcus Lucretius

(Pompeii) and not exposed to the atmosphere since the eruption of the Mount Vesuvius were subjected to

10 a controlled $\mathrm{SO}_{2}$ atmosphere and high relative humidity. These experiments were conducted in order to simulate under accelerated conditions the possible deterioration of the hematite pigment and plaster. The mineralogical transformation of the polychromy and plaster was monitored using mainly Raman spectroscopy, a non-destructive technique, but also infrared spectroscopy (FT-IR) and scanning electron microscopy energy-dispersive X-ray spectroscopy (SEM-EDS). After different exposure cycles to $\mathrm{SO}_{2}$, it

15 was confirmed that hematite red pigment $\left(\mathrm{Fe}_{2} \mathrm{O}_{3}\right)$ can be reduced into magnetite $\left(\mathrm{Fe}_{3} \mathrm{O}_{4}\right)$, which offer the darkened colour to the pigment. While $\mathrm{Fe}$ (III) from hematite is reduced into $\mathrm{Fe}$ (II) or mixed $\mathrm{Fe}$ (III) and $\mathrm{Fe}(\mathrm{II})$, the $\mathrm{SO}_{2}$ can be oxidized $\left(\mathrm{SO}_{3}\right)$ and hydrated to suffer a subsequent wet deposition $\left(\mathrm{H}_{2} \mathrm{SO}_{4}\right.$ aerosol) causing as well the transformation of calcite into gypsum. Finally, it was assessed that high concentrations of $\mathrm{SO}_{2}$ can also cause the sulphation of hematite pigment promoting its transformation into

${ }_{20}$ paracoquimbite/coquimbite $\left(\mathrm{Fe}_{2}\left(\mathrm{SO}_{4}\right)_{3} \cdot 9 \mathrm{H}_{2} \mathrm{O}\right)$. Moreover, in some areas of the deteriorated painting fragments, non-expected iron (II) sulphate and sulphite species were also identified.

\section{Introduction}

The mineralogy of the Earth evolves as a consequence of a range of physical, chemical, and biological processes. ${ }^{1}$ At large scale, 25 this evolution depends on a sequence of geochemical and petrologic processes, including volcanism and degassing, fractional crystallisation, crystal settling, assimilation reactions, metamorphism, plate tectonics, and associated large-scale fluidrock interactions. However, at small scale, it is also possible to

30 visualize how minerals and rocks can be transformed due to natural and induced weathering.

More recent is the interest of scientist for the mineralogical alterations produced in artworks and historical buildings. Several studies have been done on this field, for example, the role of 35 oxalates in the transformation of copper minerals in several artworks, ${ }^{2-4}$ the chemical transformations of iron oxide phases in CorTen steel sculptures, ${ }^{5}$ the mineralogical transformation in historical bricks, ${ }^{6}$ the blackening of red lead pigment, ${ }^{7}$ the darkening of lead chromate, ${ }^{8,9}$ etc.
40 Special attention has received the mineralogical and colour changes produced in some pigments of the wall paintings from the archaeological site of Pompeii (Italy). Many wall paintings survived the eruption of Mount Vesuvius because the pyroclastic deposits preserved wall paintings and houses until they were 45 excavated. However, since those excavations were made, some pigments have suffered chemical transformation. The most studied chemical transformations of the Pompeian pigments is the blackening or darkening process of red cinnabar $(\mathrm{HgS})$ pigment. ${ }^{10}$ Cinnabar pigment can be converted into $\mathrm{Hg}(0)$ and $\mathrm{S}(0)$ following 50 a photochemical reaction catalysed by chlorine. The metallic mercury particles can be deposited on the original cinnabar surface giving as a result the darkening process of this pigment. ${ }^{11}$ In the case of Pompeii, and considering its closeness to the sea, chlorine ions can be deposited on the surface of cinnabar pigment due to the 55 marine aerosol.

Apart from cinnabar, hematite pigment is the most used red pigment in paintings from Pompeian houses. Since ancient times, it has been affirmed that hematite red pigment is a thermically, chemically and minerallogically stable pigment. ${ }^{12}$ Hematite

\footnotetext{
${ }^{a}$ Department of Analytical Chemistry, Faculty of Pharmacy, University of the Basque Country UPV/EHU, P.O. Box 450, 01006 Vitoria-Gasteiz, Spain. Fax: +3494 50130 14; Tel: +349450130 58; E-mail: maite.maguregui@ehu.es

${ }^{b}$ Department of Analytical Chemistry, Faculty of Science and Technology, University of the Basque Country UPV/EHU, P.O. Box 644, 48080 Bilbao,Spain

${ }^{c}$ Department of Art and Cultural Studies, University of Jyväskylä, PL 25 FIN-40014, Finland

${ }^{d}$ Institute of Science and Technology in Art, Academy of Fine Arts, Schillerplatz 3, A-1010 Vienna, Austria.
} 
pigment (from the Greek haimatitis, which means "blood red") is a variety of red ochre. Like all ochre pigments, it has been used since prehistoric times. ${ }^{13}$ In the literature, no references can be found about deterioration processes of red hematite pigment. On 5 the contrary, the thermal transformation of goethite $(\mathrm{FeOOH})$ into hematite $\left(\mathrm{Fe}_{2} \mathrm{O}_{3}\right)$ is well referenced. This dehydration process can take place at $250^{\circ} \mathrm{C} .{ }^{14,15}$ If organic matter is present in the media, maghemite $\left(\gamma-\mathrm{Fe}_{2} \mathrm{O}_{3}\right)$ can be formed, and the transformation product acquire dark red or brown tonality. ${ }^{16}$

10 Modern polluted atmospheres affect the state of conservation of artworks and historical buildings and can produce also mineralogical changes. ${ }^{5,6}$ The beautiful walls and wall paintings from Pompeii have been exposed to the open air since their excavations and subsequently, they have been affected by the high 15 polluted atmosphere of Naples and surroundings. In previous works the blackening process of hematite was identified. ${ }^{17,18}$ The presence of blackened hematite red pigment areas were identified in wall paintings from the House of Marcus Lucretius, Pompeii (insula IX 3, combination of houses 5 and 24). The in situ 20 screening of those blackened or darkened hematite areas with portable Raman spectroscopy and additional analysis using microRaman spectroscopy on cross-sections taken from those areas, revealed the presence of a thin micro-layer of magnetite $\left(\mathrm{Fe}_{3} \mathrm{O}_{4}\right)$ together with gypsum and in some cases, the presence of iron (III) 25 sulphate nonahydrate (paracoquimbite and/or coquimbite). ${ }^{17,18}$

Additional thermodynamic modelling allowed to establish that the transformation of hematite into magnetite and/or (para)coquimbite is possible after a $\mathrm{SO}_{2}$ acid gas attack. ${ }^{18}$ Similar chemical thermodynamic modelling predictions have been tested with very 30 successful results in other studies. ${ }^{19,20}$

This work presents an accelerated weathering study of recently excavated fragments (around $2 \times 3 \mathrm{~cm}$ ) painted with hematite and coming from the burial of the House of Marcus Lucretius. The aim was to demonstrate if it is possible to darken the hematite under 35 pollution conditions due to $\mathrm{SO}_{2}$ gas attack. Painting fragments were subjected to $\mathrm{SO}_{2}$ impact under high relative humidity conditions in order to simulate the influence of this pollutant in the sulphation process of calcite and hematite [(para)coquimbite formation] and in the transformation of the red hematite into black 40 magnetite. The chemical/mineralogical transformation of hematite pigment and plaster were confirmed using Raman spectroscopy and in some cases Fourier Transform infrared spectroscopy (FTIR) and scanning electron microscopy energy dispersive X-ray spectroscopy (SEM-EDS).

\section{${ }_{45}$ 2. Experimental section}

\subsection{Instrumentation}

A LabRAM ARAMIS Raman confocal microscope by HORIBA Jobin Yvon implementing three excitation lasers (532, 633 and 785 $\mathrm{nm}$ ) was used to perform the Raman measurements. In this case, 50 and due to the nature of the analysed samples, the 633 and $785 \mathrm{~nm}$ laser excitation wavelengths were selected to obtain the best Raman spectral results The treatment of the spectra were carried out using the GRAMS/AI 7.02 (Thermo Fisher Scientific Inc., Waltham, USA) software.

55 An i-Series FT-IR microscope by Perkin-Elmer (Perkin Elmer, Massachusetts, USA) was used to carry out the IR measurements.
Infrared spectra were collected in transmission mode on a compression cell (sampling of crystals from the surface is required for the measurement). Infrared spectra were acquired with a 60 resolution setting of $4 \mathrm{~cm}^{-1}$ and 40 scans per acquired spectrum. The spectral range in this case was $4000-600 \mathrm{~cm}^{-1}$. Spectra were acquired with Spectrum ${ }^{\text {TM }}$ 5.3.1 software. Data-handling of FT-IR spectra was also carried out using GRAMS/AI 7.02 (Thermo Fisher Scientific Inc., Waltham, USA) software. The interpretation 65 of Raman spectra was done by comparing the sample spectra with the spectra of pure standard compounds contained in the eVISNICH database of original and decay compounds belonging to the natural, industrial and cultural heritage. ${ }^{21}$ Additional databases $\left(\right.$ RASMIN $^{22}$ and RRUFF $^{23}$ ) were also used in the assignation of 70 Raman spectra. For the infrared spectra interpretation, the obtained spectra were compared with the spectra of pure standard compounds contained in the e-VISART infrared database. ${ }^{24}$

A scanning electron microscope $\left(\mathrm{EVO}^{\circledR} 40\right.$, Carl Zeiss NTS $\mathrm{GmbH}$, Germany) coupled to an energy dispersive X-ray detector 75 (X-Max, Oxford Instruments, Abingdon, Oxfordshire, UK) was used for electron image acquisitions and elemental composition determinations of the samples. As the samples were partially conductive due to their high iron content, they were not coated with carbon or gold in order to avoid interferences in the EDS analyses. ${ }_{80}$ The elemental analysis was carried out using an $8.5 \mathrm{~mm}$ working distance, a $35^{\circ}$ take-off angle and an acceleration voltage of $20 \mathrm{KV}$. An integration time of $50 \mathrm{~s}$ was employed to improve the signal to noise ratio.

\section{${ }_{85}$ 2.2. Description of samples}

The accelerated weathering experiments were carried out with three selected wall painting fragments (fresco painting fragments like the one that showed hematite blackening process) from the house of Marcus Lucretius. The samples were recovered during the 90 excavation works in 2006-2007. Thus, these fragments had not been exposed to the open air since the year 79 AD when Mount Vesuvius erupted. Model samples were not prepared to perform the accelerated weathering experiments, because the authors of this paper believed that real Roman painting fragments extracted from 95 the same Pompeian house could have similar composition (polychromy and mortar including intonaco and arriccio) and characteristics comparing with the original painting which suffer the hematite blackening process. To perform the accelerated weathering experiments on artificially prepared wall paintings 100 making a copy of Roman fresco paintings recipe will be less realistic than doing the experiments on real Roman fresco paintings.

In order to confirm that the selected painting fragments are real 105 fresco paintings (calcite used as binder of the pigment grains) including only hematite as pigment and calcite as the plaster of the wall painting, several spectroscopic techniques were used (Raman spectroscopy mainly, but also FT-IR microscopy). Once ensured that these fragments only had in their original composition calcite 110 and hematite (possible silicates could be also present coming from the plaster and sometimes coming from possible deposits of the burial), accelerated weathering experiments were performed.

\subsection{Accelerated weathering experiments}


The accelerated weathering experiments were carried out in the Institute of Science and Technology in Art (Academy of Fine Arts) in Vienna. For that purpose, a weathering cell or hermetic closed glass box (Fig. 1) was used. The moist air stream with the corrosive 5 gas $\left(\mathrm{SO}_{2}\right)$ was generated by using a dry synthetic air flow which was provided by a compressor (Jun-Air, Germany, Model OF3014B 5) in combination with a pure air generator (Sigma-Aldrich, Austria Nitrox Model 140). The quality of the pure air was guaranteed by using high efficiency pre- and post-desiccant 10 filtration. The flow of dry synthetic air was divided into two separate streams. One part of the dry air stream was humidified in a bottle containing distilled and deionised water, and afterwards combined with the untreated airflow to the desired levels of relative humidity $(\mathrm{RH})$. The desired amount of acidifying gases 15 ( $\mathrm{SO}_{2}$ in this case, $98 \%$ purity) was batched to this humidified air stream. The humidified air stream and the selected amount of $\mathrm{SO}_{2}$ passed through a tube to the weathering cell or hermetic closed glass box (see Fig. 1).

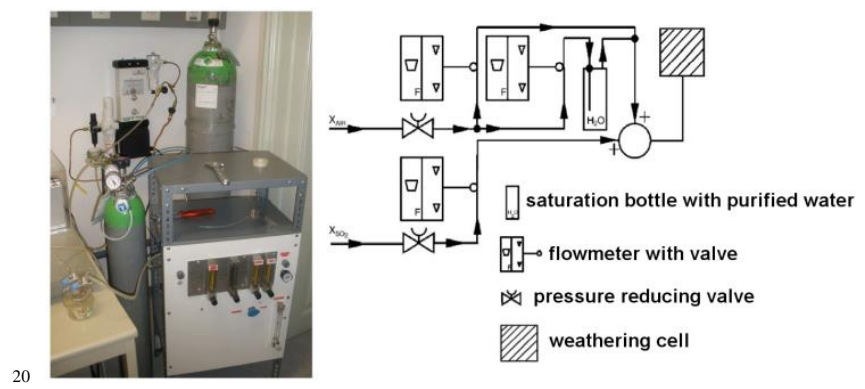

Fig. 1 Assembly of the humidified air stream and $\mathrm{SO}_{2}$ contribution system and the weathering cell (left) and a scheme of all the system (right).

25 To design the accelerated weathering experiment, it was taken into account that the wall paintings of the House of Marcus Lucretius with hematite red pigment and calcite have been exposed more or less 166 years to environment of Pompeii since they were discovered. The average concentration of $\mathrm{SO}_{2}$ in European city 30 atmospheres is more or less $65 \mu \mathrm{g} / \mathrm{m}^{3}$ or $25 \mathrm{ppb}$. The highest amount in Naples during the last 30 years has been $130 \mu \mathrm{g} / \mathrm{m}^{3}$ or $50 \mathrm{ppb}^{25}$ Considering that the experimental was conducted in accelerated conditions and taking into account the high amount of $\mathrm{SO}_{2}$ in the atmosphere near Pompeii, as an initial test $200 \mathrm{ppm}$ 35 (4000 times more than the highest values near Pompeii) of $\mathrm{SO}_{2}$ were considered to be introduced in the weathering cell.

In the experiments a 90-95\% Relative Humidity ( $\mathrm{RH})$ was used, in order to achieve the reaction between the water and the $\mathrm{SO}_{2}$ to generate the sulphuric acid necessary to start the sulphation 40 processes $\left(\mathrm{SO}_{2}\right.$ wet deposition).

\section{Results and discussion}

45 Different experiments were carried out in order to identify which kind of mineral phases can be formed after an exposure of wall painting fragments to $\mathrm{SO}_{2}$ and high humidity inside the weathering cell.
In a first experiment, wall painting fragments were introduced in 50 the weathering cell and they were undergone to $200 \mathrm{ppm} \mathrm{SO}_{2}$ and 90-95 \% Relative Humidity (RH) during 24 hours. Afterwards, a non-destructive characterization of the polychromy (hematite) and plaster (calcite) by means of Raman spectroscopy was carried out. Comparing the Raman spectra obtained from the red pigment layer 55 and the plaster before and after the exposure to the $\mathrm{SO}_{2}$, there were not identify any new mineral phase formed as a consequence of sulphation processes.

Considering this observation, the same exposed wall painting fragments were subjected to an additional weathering cycle of 24 ${ }_{60}$ hours, but increasing the amount of $\mathrm{SO}_{2}$ in the weathering cell up to $400 \mathrm{ppm}$ (8000 times more than the highest value of this acid gas in Naples atmosphere). The Raman analysis performed after this second consecutive experiment, did not revealed the presence of additional mineral phases in the polychromy and plaster.

65 Taking into account that the formation of sulphates in calcareous materials frequently follows a wet deposition of $\mathrm{SO}_{2}\left(\mathrm{H}_{2} \mathrm{SO}_{4}\right.$ formation in the surface of the wall and subsequent deposition), ${ }^{26}$ an extra amount of water inside the weathering cell was included in order to simulate the wet deposition of the $\mathrm{SO}_{2}$. Therefore, at the 70 bottom of the hermetic closed glass box, a thin layer of Milli-Q water was deposited. Under these conditions, the fragments were exposed 48 hours more to $400 \mathrm{ppm} \mathrm{SO}_{2}$ and 90-95\% of RH.

After this last chain weathering experiment, the three fragments were analyzed by means of Raman spectroscopy. On the one hand, 75 gypsum $\left(\mathrm{CaSO}_{4} \cdot 2 \mathrm{H}_{2} \mathrm{O}\right.$, showing all their Raman bands, see Fig. 2) was identified in all painting fragments in the intonaco (outer part) and also arriccio (inner part) layer of the three samples. Gypsum crystals formed in the arriccio showed an acicular appearance, while gypsum crystals formed in the intonaco showed a 80 rhombohedral appearance (see Fig. 2).

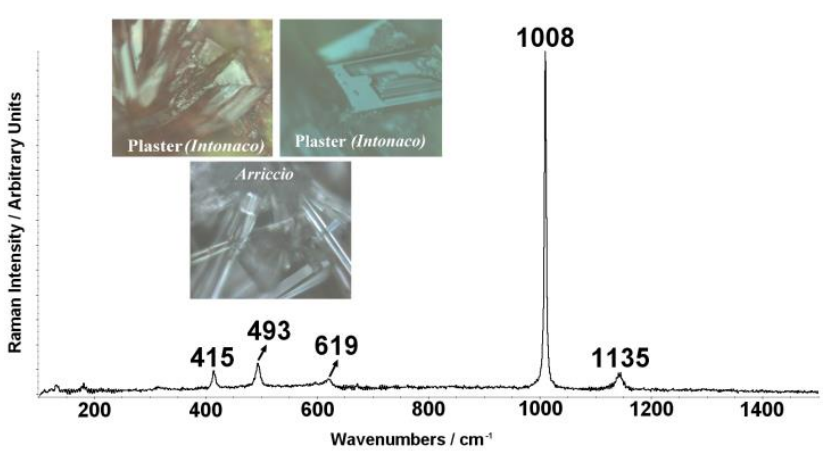

Fig. 2 Rama spectrum and microscopic images (40x objective lens) of 85 gypsum crystals formed in the outer parts of wall painting fragments (intonaco layer) and in the inner parts of the wall painting fragments (arriccio layer). 


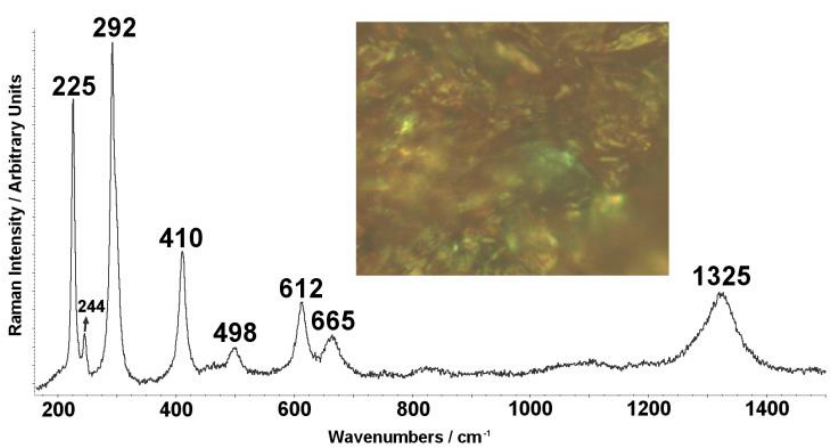

Fig. 3 Raman spectrum of black-greyish crystals on the red polychromy showing Raman bands of hematite (225, 244, 292, 410, 498, 612 and 1325 $\left.\mathrm{cm}^{-1}\right)$ and magnetite $\left(665 \mathrm{~cm}^{-1}\right)$ and a microscopic detail of those crystals 5 (40X objective lens).

Apart from gypsum, additional new mineral phases were identified in the weathered wall painting fragments. In many areas of the red polychromy (hematite), black-greyish areas were 10 identified (see these areas in the microphotography from Fig. 3). Raman measurements performed on those areas showed the presence of an additional Raman band around 660-665 $\mathrm{cm}^{-1}$, apart from Raman bands of hematite $\left(\mathrm{Fe}_{2} \mathrm{O}_{3}\right)$ pigment (see Fig. 3). This Raman band can be assigned to magnetite $\left(\mathrm{Fe}_{3} \mathrm{O}_{4}\right)$. Magnetite is a 15 mixed oxide of Fe (II) and Fe (III). In many spectra, hematite and magnetite Raman bands appeared together with the main Raman band of gypsum (see Fig. 4).

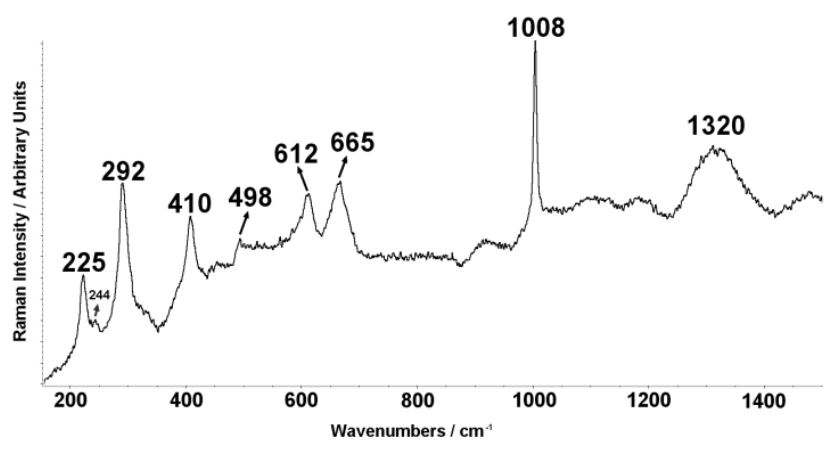

20 Fig. 4 Raman spectrum of black-greyish crystals on the red polychromy showing hematite $\left(225,244,292,410,498,612\right.$ and $\left.1320 \mathrm{~cm}^{-1}\right)$, magnetite $\left(665 \mathrm{~cm}^{-1}\right)$ and gypsum $\left(1008 \mathrm{~cm}^{-1}\right)$ Raman bands.

On the surface of the three samples, new white-reddish crystals 25 were also observed. Raman spectra obtained from those crystals showed Raman bands around 220, 280 and $1024 \mathrm{~cm}^{-1}$ (see Fig. 5). This Raman feature can be related with an iron (III) sulphate nonahydrate $\left(\mathrm{Fe}_{2}\left(\mathrm{SO}_{4}\right)_{3} \cdot 9 \mathrm{H}_{2} \mathrm{O}\right)$. The spectra acquired in the whitereddish crystals were compared with Raman spectra obtained from 30 a coquimbite mineral which was catalogued and provided by the Natural History Museum of Wien (Naturhistorische Museum). The Raman bands identified in the white-reddish crystals coincide with those obtained from the pure coquimbite mineral (see Fig. 5). Coquimbite mineral Raman spectrum is very similar to that of 35 paracoquimbite. According to literature, paracoquimbite has an additional week band around $501 \mathrm{~cm}^{-1} .^{23,27}$ This additional Raman band was not identified in the Raman measurements performed on the weathered surfaces. Apart from the individual presence of coquimbite, this mineral phase was also identified together with 40 the Raman bands of gypsum (see the spectrum at the top of Fig. 6), and also gypsum, hematite and magnetite (see the spectrum at the bottom of Fig. 6 top).

According to these results, the influence of $\mathrm{SO}_{2}$ in the transformation of hematite pigment into magnetite and coquimbite, 45 together with the sulphation process of the calcite from the intonaco, calcite coming from the binder of the fresco painting and calcite from the arriccio, was clearly proved. In our previous study, ${ }^{18}$ magnetite was pointed as the responsible of the blackening processes of hematite pigment from wall paintings of the House of 50 Marcus Lucretius in Pompeii.

Apart from the Raman evidences, thermodynamic study also predicted that magnetite could be formed as a consequence of $\mathrm{SO}_{2}$ attack. ${ }^{18}$ Moreover, in that work, it was stated that coquimbite and gypsum can be formed as a consequence of $\mathrm{SO}_{2}$ wet deposition 55 (sulphation of hematite pigment and calcite from the plaster and binder). While $\mathrm{SO}_{2}$ is oxidized into $\mathrm{SO}_{3}$ and hydrated/deposited on the surface of the painting as $\mathrm{H}_{2} \mathrm{SO}_{4}$, hematite red pigment $\left(\mathrm{Fe}_{2} \mathrm{O}_{3}\right)$ can be reduced into magnetite $\left(\mathrm{Fe}_{3} \mathrm{O}_{4}\right)$. In the same way, hematite can be sulphated and transformed into coquimbite. The presence 60 of hematite, magnetite, gypsum and coquimbite in the same spectrum (see Fig. 6) indicates that in some areas the hematite pigment is not completely transformed into magnetite, but it is partially transformed into magnetite and coquimbite. The present work supports the thermodynamic predictions as well as the ${ }_{65}$ Raman evidences about the formation of gypsum, coquimbite and magnetite identified in the wall paintings of the House of Marcus Lucretius.

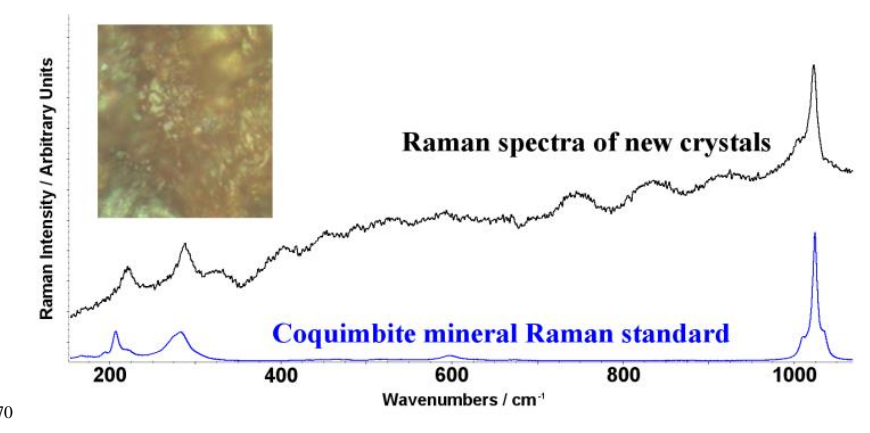

Fig. 5 Raman spectra of the white-reddish crystals and coquimbite mineral and a microscopic detail of the crystals where Raman measurements were performed on painting fragments. 


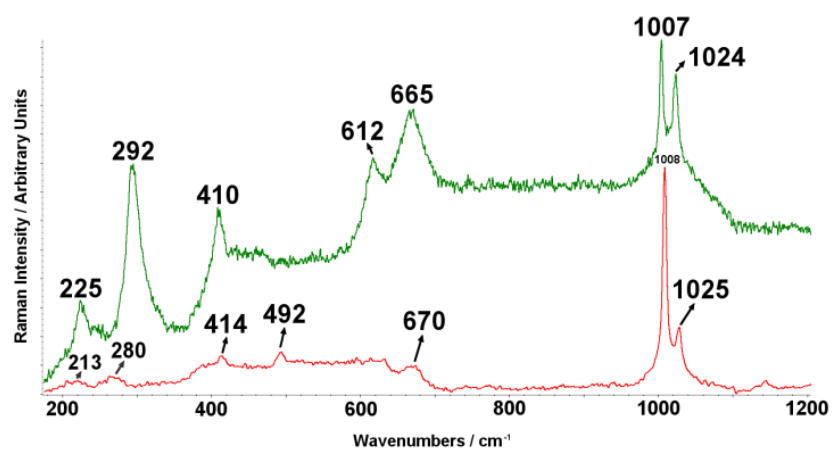

Fig. 6 Raman spectrum of hematite $\left(225,292,410\right.$ and $\left.612 \mathrm{~cm}^{-1}\right)$, magnetite $\left(665 \mathrm{~cm}^{-1}\right)$, gypsum $\left(1007 \mathrm{~cm}^{-1}\right)$ and coquimbite $\left(1024 \mathrm{~cm}^{-1}\right)$ on the top, and Raman spectrum of gypsum $\left(414,492,670\right.$ and $\left.1008 \mathrm{~cm}^{-1}\right)$ and 5 coquimbite $\left(213,280\right.$ and $\left.1025 \mathrm{~cm}^{-1}\right)$ on the bottom.

Apart from gypsum, magnetite and coquimbite identification, in some Raman spectra two additional Raman bands at 989 and 962 $\mathrm{cm}^{-1}$ (see Fig. 7) respectively were identified. These Raman bands 10 were only identified in two spectra among more than 150 Raman measurements done on each exposed fragment. Therefore, it can be affirm that the presence of the compound/compounds linked to these bands is minority with respect to the rest of the compounds (original and newly formed ones) present. With the Raman 15 spectroscopy it is possible to focus specific and individual crystals and detect their Raman scattering. Considering the punctual or low presence of this/these compound/compounds on the measured surfaces, other analytical techniques (i.e. X-Ray diffraction) that give information about the molecular composition of the sample 20 are not going to be able to detect this/these compound/compounds present in a low percentage with respect to the total composition of the sample.

In the mentioned two spectra, the bands at 989 and $962 \mathrm{~cm}^{-1}$ 25 appear together with the main band of gypsum $\left(1008 \mathrm{~cm}^{-1}\right)$. The areas where these two Raman bands were identified were analyzed using an energy dispersive $\mathrm{X}$-ray spectrometer. The elements present in these areas were $\mathrm{C}, \mathrm{O}, \mathrm{Mg}, \mathrm{Al}, \mathrm{Si}, \mathrm{S}, \mathrm{K}, \mathrm{Ca}$ and $\mathrm{Fe}$ (see Fig. 8). Elements such as $\mathrm{Al}, \mathrm{Si}, \mathrm{K}$ and $\mathrm{Mg}$ can be present in the 30 sample being part of aluminosilicate aggregates that can be present in the plaster of the exposed fresco fragments.

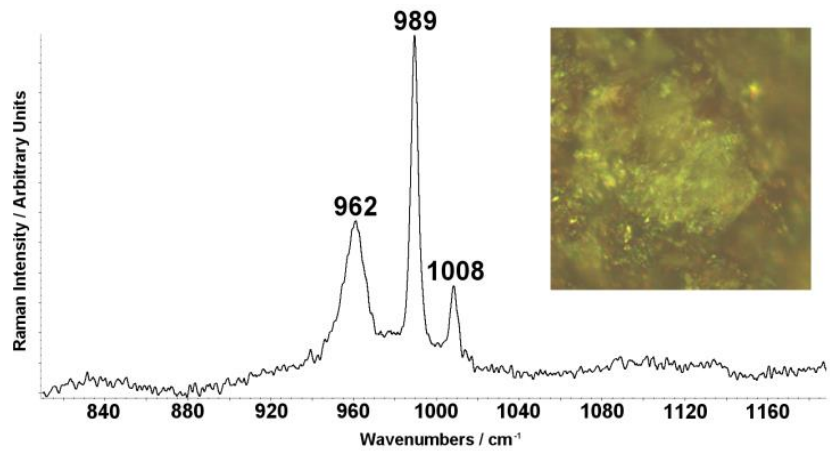

Fig. 7 Raman spectrum of new crystals (see microscopic image detail) 35 showing the main Raman band of gypsum $\left(1008 \mathrm{~cm}^{-1}\right)$ and two Raman bands at 989 and $962 \mathrm{~cm}^{-1}$.
Considering the elemental composition of these crystals and the position of both Raman bands, it can be said that both bands are 40 related to sulphates and/or sulphites.

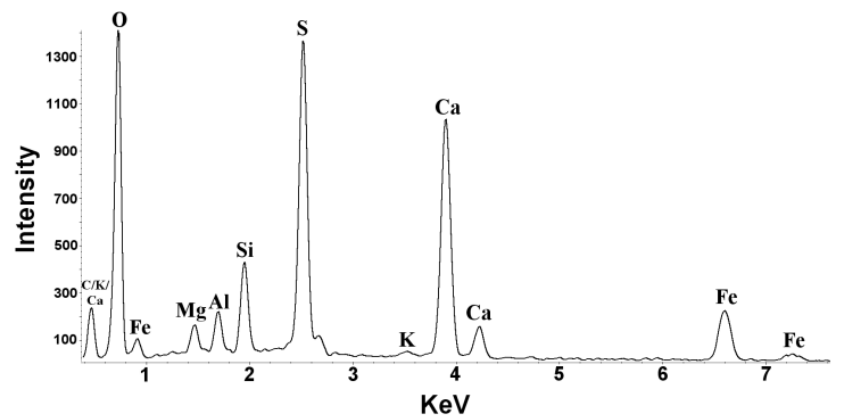

Fig. 8 EDS spectrum of crystal aggregates where 988 and $958 \mathrm{~cm}-1$ Raman bands were identified.

45

Ettringite $\left[(\mathrm{CaO})_{6}\left(\mathrm{Al}_{2} \mathrm{O}_{3}\right)\left(\mathrm{SO}_{3}\right)_{3} \cdot 32 \mathrm{H}_{2} \mathrm{O}\right]$ and thaumasite $\left[\mathrm{Ca}_{3} \mathrm{Si}\left(\mathrm{CO}_{3}\right)\left(\mathrm{SO}_{4}\right)(\mathrm{OH})_{6} \cdot 12\left(\mathrm{H}_{2} \mathrm{O}\right)\right]$ have their main Raman band around 984 and $989 \mathrm{~cm}^{-1} .{ }^{28}$ Unfortunately, it is not common or it is not referenced that in an ancient mortar ettringite/thaumasite can 50 be formed as a consequence of an interaction between the mortar and the $\mathrm{SO}_{2} \cdot{ }^{29}$ However, it is well-known the formation of ettringite and also thaumasite in concrete and Portland cement. ${ }^{30}$ The formation of ettringite happens when gypsum reacts with anhydrous calcium aluminates in a through-solution reaction, but 55 it is difficult to take place in ancient samples. In previous Raman analysis, it was confirmed that the plaster from the weathered wall painting fragments also contain aluminosilicates of calcium and magnesium in its original composition, thus, this aluminosilicates of calcium could react with the sulphates and evolve into ettringite 60 and/or thaumasite.

A recent study ${ }^{31}$ also found a Raman band around $980 \mathrm{~cm}^{-1}$ together with Raman bands of gypsum and coquimbite in products used in illuminations, lakes and inks. The authors assigned this Raman band to a possible iron sulphate mixture of $\mathrm{Fe}(\mathrm{II})$ and ${ }_{65} \mathrm{Fe}(\mathrm{III})$. Considering this observation, the Raman band at $988 \mathrm{~cm}^{-1}$ could belong to an iron sulphate. Rozenite's $\left(\mathrm{FeSO}_{4} \cdot 4 \mathrm{H}_{2} \mathrm{O}\right)$ main band ${ }^{24}$ is located at $991 \mathrm{~cm}^{-1}$ and szomolnokite's $\left(\mathrm{FeSO}_{4} \cdot \mathrm{H}_{2} \mathrm{O}\right)$ main band ${ }^{24}$ is located at $989 \mathrm{~cm}^{-1}$. Therefore, in our accelerated weathered samples, the presence of szomolnokite is more probable 70 than that of rozenite.

In the same spectra, together with the band at $989 \mathrm{~cm}^{-1}$ and sometimes in presence of the main band of gypsum (see Fig. 7), a band at $962 \mathrm{~cm}^{-1}$ can also be observed. This strong band can be assigned to the symmetric stretching vibration of the $\mathrm{SO}_{3}{ }^{2-}$ ion. ${ }^{32}$ 75 Some authors related this Raman band with $\mathrm{FeSO}_{3} \cdot 3 \mathrm{H}_{2} \mathrm{O} .{ }^{33}$ The presence of magnetite, indicate that in certain moments of the reaction, iron in two oxidation states (II and III) can be present on the surface of the wall painting fragments. Moreover, the hydrated $\mathrm{SO}_{2}\left(\mathrm{H}_{2} \mathrm{SO}_{3}\right)$ can be partially oxidized into $\mathrm{H}_{2} \mathrm{SO}_{4}$, but a percentage 80 of $\mathrm{H}_{2} \mathrm{SO}_{3}$ could remain on the surface of the painting fragments, and therefore, a reaction between $\mathrm{H}_{2} \mathrm{SO}_{3}$ and reduced hematite (Fe(II)) could take place, giving as a result the formation of iron (II) sulphite with different amount of hydration waters.

To support the Raman analyses, infrared spectra were also 85 collected. Some crystals from the surface of the red hematite paintings were sampled carefully and analyzed by means of FTIR. All the obtained spectra belonged to gypsum. This is logical, 
since the biggest crystals that can be sampled and deposited on the diamond cell are those of gypsum. However, in some white amorphous crystals, in addition to the infrared features of gypsum (infrared band at 3541, 3414, 1683, 1623, 1119, 672 and $601 \mathrm{~cm}^{-}$ $5_{5}^{1}$ ) another additional band at $948 \mathrm{~cm}^{-1}$ was identified (see Fig. 9). This last IR band can be related with the $\mathrm{SO}_{3}{ }^{2-}$ group vibration.

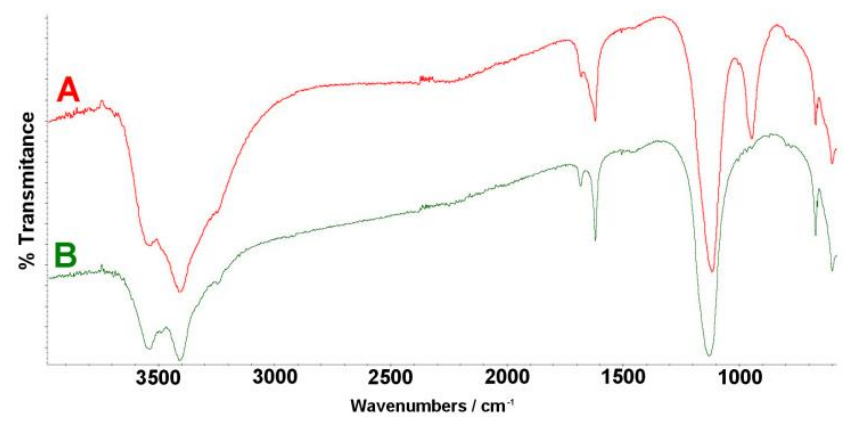

Fig. 9 Infrared spectra of two crystals formed after the accelerated 10 weathering experiments showing the infrared bands of gypsum (B spectrum) and gypsum + strong IR band of sulphite at $948 \mathrm{~cm}^{-1}$ (A spectrum).

\section{Conclusions}

Thanks to the use of accelerated weathering experiments and 15 subsequent non-destructive characterization of samples using spectroscopic techniques such as Raman spectroscopy mainly, but also infrared spectroscopy and energy dispersive X-ray spectroscopy (EDS), it was possible to assess that hematite red pigment $\left(\mathrm{Fe}_{2} \mathrm{O}_{3}\right)$ can be reduced into magnetite $\left(\mathrm{Fe}_{3} \mathrm{O}_{3}\right)$ in presence 20 of $\mathrm{SO}_{2}$. This mineralogical transformation is the responsible of the colour change of the pigment from red to darkened red. At the same time, the $\mathrm{SO}_{2}$ can be oxidized into $\mathrm{SO}_{3}$ (complementary redox reaction to the hematite reduction) and hydrated on the surface of the painting giving as a result the wet deposition of $\mathrm{H}_{2} \mathrm{SO}_{4}$. The 25 formed $\mathrm{H}_{2} \mathrm{SO}_{4}$ can react with the calcite giving as a result the gypsum formation. The sulphuric acid can also react with the hematite giving as a result the sulphation process of iron (III). Under this conditions, the most probable iron (III) sulphate that can be formed is coquimbite $\left(\mathrm{Fe}_{2}\left(\mathrm{SO}_{4}\right)_{3} \cdot 9 \mathrm{H}_{2} \mathrm{O}\right)$. Nevertheless, the 30 possible formation of paracoquimbite, a polymorph of coquimbite, cannot be ruled out.

After conducted all the weathering experiments, it is necessary to highlight the importance of an extra contribution of water in the reaction media to simulate the wet deposition of atmospheric $\mathrm{SO}_{2}$ 35 pollutant as sulphuric acid, and therefore, to achieve the formation of magnetite, coquimbite and gypsum.

Unexpected results were also obtained, such as the presence of a Raman band at $989 \mathrm{~cm}^{-1}$, which can be related with thaumasite and/or an iron (II) sulphate, probably szomolnokite $\left(\mathrm{FeSO}_{4} \cdot \mathrm{H}_{2} \mathrm{O}\right)$.

40 However, the possible formation of other iron (II) sulphates, such as rozenite, etc. should be taken into account. Additionally, the $\mathrm{Fe}$ (II) formed in the reduction of the hematite pigment can react on the surface of the painting with the non-oxidized and hydrated $\mathrm{H}_{2} \mathrm{SO}_{3}$ to form an iron (II) sulphite. The formation of sulphites was 45 also demonstrated with the FT-IR observations, since in some spectra an IR band at $948 \mathrm{~cm}^{-1}$ related with $\mathrm{SO}_{3}{ }^{2-}$ group vibration was identified This weathering experiments demonstrate that apart from sulphates, sulphites can be formed after the attack of $\mathrm{H}_{2} \mathrm{SO}_{3}$ (coming from the hydration of $\mathrm{SO}_{2}$ ). In real exposed samples, the
50 common species that are usually detectable after $\mathrm{SO}_{2}$ impact are sulphates, because with the pass of the time, sulphites can be oxidized into sulphates.

As a final conclusion, it can be said that the proposed accelerated weathering experiments are valid to assess the decaying pathway ${ }_{55}$ proposed in a previous study ${ }^{18}$ carried out on wall paintings from the House of Marcus Lucretius (Pompeii) to justify the new mineralogical phases formed during the darkening process of the hematite pigment (calcite sulphation from plaster and hematite red pigment transformation into black magnetite and coquimbite) ${ }_{60}$ induced by atmospheric pollution.

\section{Acknowledgements}

The authors thank the Finnish EPUH project group, especially emeritus Professor Paavo Castren and Docent Antero Tammisto (Helsinki University), for providing the wall painting fragments 65 used for these experiments. The authors also thank to Ira Rabin from the Federal Institute for Materials Research and Testing in Berlin for all the support given, and to the Naturhistorisches Museum (Museum of Natural History) in Vienna for lending the coquimbite mineral. This work was supported by the COST STSM 70 action D-42-6420, the University of the Basque Country UPV/EHU through the UFI Global Change and Heritage (ref UFI11/26) and the Spanish Government (MINECO) through the DEMBUMIES project (ref BIA2011-28418).

\section{References}

751 R. M. Hazen, D. Papineau, W. Bleeker, R. T. Downs, J. M. Ferry, T. J. McCoy, D. A. Sverjensky and H. Yang, Am. Mineral., 2008, 93, 16931720.

2 K. Castro, A. Sarmiento, I. Martınez-Arkarazo, J. M. Madariaga and L.A. Fernandez, Anal. Chem., 2008, 80, 4103-4110.

803 C. Miliani, B. Doherty, A. Daveri, A. Loesch, H. Ulbricht, B. G. Brunetti and A. Sgamellotti, Spectrochim. Acta A, 2009, 73, 587-592.

4 A. Zoppi, C. Lofrumento, N. F. C. Mendes and E. M. Castellucci, Anal. Bioanal. Chem., 2010, 397, 841-849.

5 J. Aramendia, L. Gomez-Nubla, K. Castro, I. Martinez-Arkarazo, D.

85 Vega, A. Sanz Lopez de Heredia, A. Garcia Ibanez de Opakua, J. M. Madariaga, J. Raman Spectrosc., 2012, 43, 1111-1117.

6 M. Maguregui, A. Sarmiento, R. Escribano, I. Martinez-Arkarazo, K. Castro and J. M. Madariaga, Anal. Bioanal. Chem., 2009, 395, 21192129.

907 S. Aze, J-M Vallet, M. Pomey, A. Baronnet and O. Grauby, Eur. J. Mineral., 2007, 19, 883-890

8 L. Monico, G. Van der Snickt, K. Janssens, W. De Nolf, C. Miliani, J. Dik, M. Radepont, E. Hendriks, M. Geldof and M. Cotte, Anal. Chem., 2011, 83, 1224-1231.

959 L. Monico, G. Van der Snickt, K. Janssens, W. De Nolf, C. Miliani, J. Verbeeck, H. Tian, H. Tan, J. Dik and M. Radepont, Anal. Chem., 2011, 83, 1213-1223.

10 M. Cotte, J. Susini, N. Metrich, A. Moscato, C. Gratziu, A. Bertagnini and M. Pagano, Anal. Chem., 2006, 78, 7484-7492.

10011 K. Keune and J. J. Boon, Anal. Chem., 2005, 77, 4742-4750.

12 G.R. Rapp, Archaeomineralogy, 2009, Springer-Verlag Berlin Heidelberg, e-ISBN: 978-3-540-78594-1. 
13 N. Eastaugh, V. Walsh, T. Chaplin, R. Siddall, Pigment Compendium, A dictionary of historical pigments, 2004, Elsevier ButtenworthHeinemann, Oxford, UK, e-ISBN: 978-1-136-37385-5.

14 M-P. Pomiès, M. Menu, C. Vignaud, Archaeometry, 1999, 41, 275-285.

515 H.D. Ruan, R.L. Frost, J.T. Kloprogge, Spectrochim. Acta A, 2001, 57, 2575-2586.

16 S. Gialanella, R. Belli, G. Dalmeri, I. Lonardelli, M. Mattarelli, M. Montagna, L. Toniutti, Archaeometry, 2011, 53, 950-962.

17 M. Maguregui, U. Knuutinen, K. Castro and J. M. Madariaga, J. Raman 10 Spectrosc. 2010, 41, 1110-1119.

18 M. Maguregui, U. Knuutinen, I. Martínez-Arkarazo, K. Castro and J. M. Madariaga, Anal. Chem., 2011, 83, 3319-3326.

19 M. Maguregui, A. Sarmiento, I. Martinez-Arkarazo, M. Angulo, K. Castro, G. Arana, N. Etxebarria, J. M. Madariaga, Anal. Bioanal. Chem.,

15 2008, 391, 1361-1370.

20 M. Pérez-Alonso, K. Castro, M. Alvarez and J. M. Madariaga, Anal.Chim. Acta, 2004, 524, 379-389.

21 M. Maguregui, N. Prieto-Taboada, J. Trebolazabala, N. Goienaga, N. Arrieta, J. Aramendia, L. Gomez-Nubla, A. Sarmiento, M. Olivares, J.

20 A. Carrero, I. Martínez-Arkarazo, K. Castro, G. Arana, M. A. Olazabal, L. A. Fernandez and J. M. Madariaga, Book of Abstract of the 1st International Congress of Chemistry for Cultural Heritage (ChemCH), 2010, p. 168

22 http://www.aist.go.jp/index_en.html [last accessed 15 Sept. 2012].

$2523 \mathrm{http}: / /$ rruff.info/ [last accessed 26 Sept. 2012].

24 K. Castro, M. Pérez, M. D. Rodríguez and J. M. Madariaga, Anal. Chem., 2003, 75, 214A-221A.

$25 \mathrm{http}: / / \mathrm{www}$.arpa.veneto.it/home2/htm/home.asp [last accessed on 2010 May $28^{\text {th }}$ [last accessed $19^{\text {th }}$ November 2012].

3026 G. Cultrone, A. Arizzi, E. Sebastián and C. Rodriguez-Navarro., Environ. Geol., 2008, 56, 741-752.

27 Z.C. Ling, A. Wang, Icarus, 2010, 209, 422-433.

28 M. Chollet, M. Horgnies, Surf. Interface Anal., 2011, 43, 714-725.

29 C. Sabbioni, G. Zappia, J. Aguilera, F. Puertas, K. Van Balen, E.E.

35 Toumbakari, Atmos. Environ., 2001, 35, 539-548.

30 K.N. Jallad, M. Santhanam, M.D. Cohen, D. Ben-Amotz, Cement Concr. Res., 2001, 31, 953-958.

31 M. Bicchieri, M. Monti, A. Sodo, G. Piantanida, 1st International Congress ChemCH, Ravena, Italy, 2010, p.69.

4032 V.P. Verma, Thermochim. Acta, 1985, 89, 363.

33 Y-S- Choi, S. Nesic, S. Yound, Environ. Sci. Technol., 2010, 44, $933-$ 0238. 